\title{
Smart cities and innovative governance systems: a reflection on urban living labs and action research
}

\author{
DIANA SOEIRO
}

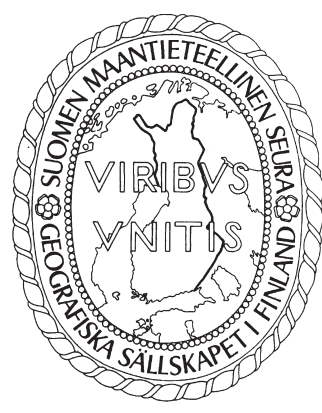

Soeiro, D. (2021) Smart cities and innovative governance systems: a reflection on urban living labs and action research. Fennia 199(1) 104-112. https://doi.org/10.11143/fennia.97054

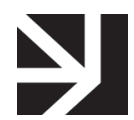

Urban Living Labs (ULL) are sites that allow different urban actors to design, test and learn from socio-technical innovations. In this article, I investigate the epistemological roots of ULL, claiming that this new instrument in the realm of urban planning strongly relies on action research, a methodology designed in the 1940s. I explore to what extent ULL and action research are different, identifying past obstacles of action research to design more successful ULL. This paper establishes that ULL are a key element to implement social innovation and that social innovation should lead technological innovation and the recent smart city model to promote smart sustainable cities. The article was prepared in the aftermath of the project "ROCK" (2017-2020) on cultural heritage as a driver for urban regeneration, where ULL played a central role being highly relevant in the context of urban regeneration policies. Key findings support that ULL can contribute to finding a balance between top-down and bottom-up strategies and its comparative qualitative analysis would improve the methodology. Moreover, public and private cooperation should be encouraged and government should lead and act as a key player in innovation strategies. Lastly, geography can contribute to these new challenges by framing past approaches, projecting the future of cities, and finding ways to make them become a reality.

Keywords: sustainable development, urban regeneration, technology, general systems theory, future studies, social innovation, urban living labs

Diana Soeiro (https://orcid.org/0000-0002-6238-8042), Instituto de Ciências Sociais, Universidade de Lisboa (ICS-UL), Av. Prof. Aníbal Bettencourt 9, 1600-189 Lisboa, Portugal. E-mail: dianasoeiro.drphil@gmail.com

\section{Introduction}

Technological innovation is at the forefront of the smart city concept, impacting the dynamics of cities as we know them, from planning to managing, to daily livability. However, is technological innovation enough to propel the smart city concept? My main claim is that the biggest challenge to successful implementation of the smart city concept is the design of innovative governance systems. The assumption behind this claim is that technological innovation should not be pursued for its own sake, but ultimately to promote and propel social, cultural, economic and ecological innovation. Otherwise, a Creative Commons Attribution 4.0 International License. 
we may have cities that are smart but not sustainable. This process calls for an all-encompassing vision and this can be challenging. Here I will assess a recent methodological approach, Urban Living Labs (ULL). These are sites that allow different urban actors to design, test and learn from sociotechnical innovations (von Wirth et al. 2019). To better grasp what is at stake in the ULL methodology, I conduct an epistemological investigation in order to identify its roots. I argue that ULL stem from General Systems Theory (from now on: Systems Theory) - a theory that also encompasses 'action research', which encourages research to be conducted in close connection with a given area and its inhabitants. Particularly celebrated in the 1970s and 1980s, it became heavily criticised for its lack of results and impractically due to its (too) wide trans-/interdisciplinary scope. The aim is to learn if ULL will be faced with similar impracticalities. In addition, I aim to explore whether the smart city concept with an emphasis on existing technologies and new governance systems can contribute to overcoming past obstacles posed by Systems Theory through ULL. I conclude by identifying how ULL can encourage the exploration of innovative governance systems; claiming a balance between bottom-up initiatives and top-down policies and reflecting on what role geography will play in this.

\section{Background}

This article stems from an active partnership with the project "ROCK - Regeneration and Optimisation of Cultural heritage in creative and Knowledge cities" (2017-2020), funded by the European Union under the Horizon 2020 (ROCK 2020) programme. The project involved seven role model cities (Athens, Cluj-Napoca, Eindhoven, Liverpool, Lyon, Turin and Vilnius) and three replicator cities (Bologna, Lisbon and Skopje) relying on action research, innovative governance strategies and Urban Living Labs (ULL) as methodology. Lisbon aimed to promote innovative cultural initiatives and to attract new talents from the creative industries by developing an ICT infrastructure using the ULL approach. In its aftermath, the project sparked in-depth reflection on its methodological foundations and this is what it is presented here, while attempting to frame it within current literature.

The above-mentioned project took an interdisciplinary approach and this article will have an interdisciplinary nature. As much as interdisciplinarity is praised in academic circles, when put into action to tackle a given subject, it is often perceived as "confusing" or "lacking a rationale". It can therefore be helpful to state beforehand that my academic background encompasses Philosophy, Urban Studies and Economics and Public Policy. The subject of ULL is itself multi-/interdisciplinary and its heterogeneous nature brings advantages and disadvantages, as assessed recently by Hossain, Leminen and Westerlund (2018) in a comprehensive literature review. However, in an increasingly complex world, interdisciplinary approaches become increasingly necessary. Therefore, it is important to learn to establish a dialogue across disciplines, respecting each person's area of expertise and broad-mindedly listening to what others have to say, being available to bridge any gap.

It is highly relevant to bear interdisciplinarity in mind, as ULL stem from Urban Planning and I claim that their foundations are grounded in a previous approach, Systems Theory. This theory quickly spread its influence, stressing the importance of adopting a trans-/interdisciplinary methodology to formulate solutions that can effectively solve practical societal problems. Part of this theory is 'action research', with its origins in social psychology (Lewin 1946), which aimed at closing the gap between theory and practice. ULL call for a similar holistic disciplinary approach, having the potential to become a significant research element in several disciplines (Geography, Economics, Public Policy, Psychology, Sociology, Anthropology and several others) articulating actors, knowledge and processes. The future of the future city is interdisciplinary (Keith et al. 2020). How to implement ULL successfully? Are we now in a better position than before to overcome the well-known obstacles faced by Systems Theory? In line with Jones' (2019) recent plea, I agree that geography has a significant contribution to make when it comes to identifying new strategies that allow us to better govern the future, aiming at contributing to more effective spatial justice. For example, Roux and Marron (2016) have demonstrated the role of urban geography in mapping living labs' geographical distribution. This close observation revealed the resolutely urban nature of these open-innovation systems that play an increasingly important role for metropolises, going hand-in-hand with economic growth and innovation. 


\section{The sustainable 'smart city', beyond technology}

Smart cities lay their foundations on data and it is crucial to design infrastructures to effectively sort, store and analyse them. In this context, connectivity, security and privacy issues are closely related topics that have also been receiving a lot of attention.

A significant part of contemporary issues in global contemporary society are consistently related to the future of cities. In a scenario of growing complexity, a variety of disciplines feel called to contribute towards better urban environments. Urban geography renovates its relevance as the discipline that embodies research's gravitational centre on cities and urban processes (Walker 2012; Wiig \& Wyly 2016). ULL deeply impact interactions within cities, translating into structural and behavioural changes that it is relevant to further investigate in the context of Urban Geography, in particular in what concerns governance (Caprotti \& Cowley 2017; Kronsell \& Mukhtar-Landgren 2018).

Technological innovation is at the centre stage of the Smart City concept (SC) (Yigitcanlar et al. 2019). Concomitantly, it has been argued that the SC cannot rely on the potential of technology alone, but should deploy a well-designed policy framework (Lam \& Ma 2019). The origins and definition of the SC concept confirm this, revealing that the true challenge resides not in technology, but governance.

Yigitcanlar and colleagues (2018) state that the smart city concept originated in the mid-1800s to describe new cities in the American West that were efficient and self-governed. This concept resurged in the 1990s under the concept of smart growth, referring mainly to sustainable urbanisation. Since then, the SC concept has evolved to encompass any form of technological innovation in the planning, development, operation and management of cities. The term SC does not have a consensual definition, but up until recently, it seemed to focus on how to utilise information technology in the urban realm (Goodspeed 2015). Since then, no matter which definition we are dealing with, there seems to be a growing body of literature that points to the multidimensional character of the SC concept as encompassing other realms that go beyond technology (see literature review by Yigitcanlar and others (2018), which presents and discusses twenty SC definitions, differentiating it from other concepts such as sustainable city, digital city, intelligent city, ubiquitous city, techno-centric city, creative city and knowledge city).

Smart cities are highly complex sociotechnical systems. Information Technology artefacts can play a role in social change, but they do not eliminate the social and political dimensions of cities (Lara et al. 2016; Almeida et al. 2018). Moreover, when it comes to 'innovation', a concept frequently associated with the SC, it has been proved that, alone, it is not the sole ingredient for success in smart cities (Gaffney \& Robertson 2016). Nevertheless, innovation in the scope of SC tends to be understood exclusively in conjunction with knowledge and economic growth, which are linked as follows: the more SC policies stimulate the innovation that increases a city's stock of knowledge, the greater the contribution to economic growth (as innovation is acknowledged to be one of its main drivers). This correlation, when measured, for example, through an increase of patents, meaning knowledge (Caragliu \& del Bo 2018), reveals a very poor understanding of the concept of innovation. Nowadays, the concept of innovation needs to be expanded and acknowledged as relevant beyond economics, as was the case with the concept of sustainability.

For many centuries, the concept of innovation was perceived as disruptive and was not welcomed. However, during the $19^{\text {th }}$ century, it became associated with mainstream economics and the idea of progress, and its success or failure was measured through the gross domestic product (GDP) (Godin 2015). The concept of sustainable development had a decisive moment with the Brundtland Report (Brundtland Commission 1987) when it was claimed that it encompassed three pillars: environmental, social and economic, representing a significant turning point in public policies around the world, culminating more recently in the United Nations 2030 Sustainable Development Goals Agenda (Soeiro 2020a). This is why the emergence of the concept of 'sustainable innovation' is relevant (Boons \& McMeekin 2019). It is still, somehow, a paradox because although sustainability has opened up its scope, innovation seems reluctant to. Up until now, in heterodox economics (all the branches of which are against a neoliberal approach), the social and ecological realms have proved to be a concern under the concept of 'social innovation' (Godin \& Gaglio 2019) - which is discussed below. 
In the last couple of years, recent literature has shown that technology and innovation concerning the SC lack the ecological and social realm. The recent concept of 'smart urbanism' (McFarlane \& Söderström 2017) indicates a need to find alternative models beyond mainstream economics and technology. Following the rationale of reference geographers like David Harvey and Edward W. Soja, ULL, in particular, were claimed to be recent contemporary elements that contribute to the neoliberal city (Cardullo et al. 2018). Goodspeed $(2015,11)$ argues for the need for a "sociotechnical theory of action that encompasses assumptions about the nature of urban problems and how they should be solved". This is done by developing local municipal innovation and the incorporation of Information Technology into cooperative urban planning. And also by empirically investigating the role of contextual factors and their potential influence on SC governance components and outcomes.

\section{ULL and social innovation: the foundations of 'the future of cities'}

A relevant methodology that aims to foster local governance innovation is $U L L$, an open user-centred environment for networked innovation development (Leminen \& Westerlund 2012) centred around a city or a given territory. ULL are an open system but the methodology and definition are not consensual. According to Schuurman, De Marez and Ballon (2017), the European Living Labs movement started in 2006 when the European Commission officially declared its support by encouraging projects to advance, coordinate and promote a common European innovation system based on Living Labs. That same year, it established the European Network of Living Labs (ENoLL) to foster innovation (EC 2016; ENoLL 2020). There are five contexts associated with Living Labs (Schuurman et al. 2017): 1) an innovation system consisting of organised and structured multidisciplinary networks fostering interaction and collaboration, 2) real-life or in vivo monitoring of a social setting generally involving experimentation of a technology, 3) an approach for involving users in the product development process, 4) organisations facilitating the network, maintaining and developing its technological infrastructure and offering relevant services, and 5) the European movement itself.

\section{Are ULL an adequate methodology for promoting social innovation?"}

To answer, I first investigate the theoretical origins of Living Labs. This takes us beyond the realm of governance and policy and leads us towards the dominion of system change, where innovation is perceived as a system that comprises technologies, social media (of innovation organisations) and institutions (both formal and informal) (Boons \& McMeekin 2019, 19-20). To explore this connection, I start briefly by addressing the main references in Systems Theory (von Bertalanffy, Parsons, Luhmann and Agazzi), aiming at identifying its fundamentals and how it can contribute to a better understanding of the foundations of ULL. Furthermore, I look into the advantages and disadvantages of these foundations.

Second, at a more practical level, I reflect on the tension between government and governance, arguing along with economist Mazzucato $(2013,2018)$ for a renewed understanding of government in innovation. I argue that cities and urban centres are key to understanding the relationship between both and are a powerful element for encouraging, in particular, social innovation.

Last, I assess whether ULL methodology is adequate to promote social innovation. As a reference, I use Lewin's concept of 'action research', which, within Systems Theory, represents the complexity systems approach, which I identify as being the one that is closest to ULL methodology. I analyse the advantages and disadvantages of 'action research' and ULL at several stages: design, implementation, management, outputs and outcome phases.

In this paper, I call for an encompassing vision so that urban innovation can move forward, beyond governance and technology, putting sustainability (economic, ecological and social) at the centre stage. We are interested to know if 'action research' and ULL are the way to achieve this.

\section{Can ULL and 'action research' promote sustainable cities?}

Innovation is no longer undertaken solely by Research \& Development organisations or academic institutions. Users are increasingly participating in all stages of innovation processes (Leminen et al. 
2013). More importantly, innovation does not originally refer to technological innovation. Rather, innovation is primarily a political concept (Godin 2015, 101). To explore whether ULL and 'action research' can promote sustainable cities, we begin by clarifying the concept of Living Labs and then proceed to address 'action research'.

Living Labs can be thematic or have a more territorial/regional basis (like ULL). It is expected that ULL become a more common methodology in the future (Macrorie et al. 2019) and it has recently been acknowledged the ULL play a significant role on sustainability transitions (von Wirth et al. 2019). It is therefore important to understand its potential. Bulkeley and colleagues (2019) propose a taxonomy of ULL in order to facilitate implementation. This can be helpful because it can contribute to mitigate the link between ULL and the perpetuation of a neoliberal governance that confines ULL within traditional governance systems (Perng \& Maalsen 2019). The integration of users into product development as co-producers is imperative for success in the Living Labs model because it reveals their latent needs and enables unforeseen outcomes (Leminen \& Westerlund 2012). Creating real-life test and experimentation environments, co-producers can co-create innovations in a trusted, open ecosystem that enables business and societal innovation. These are user-driven and human-centric events that employ four main activities: 1) co-creation: co-design by users and producers, 2) exploration: discovering emerging usages, behaviours and market opportunities, 3) experimentation: implementing live scenarios within communities of users, and 4) evaluation: assessment of concepts, products and services according to socio-ergonomic, socio-cognitive and socio-economic criteria (Europeana 2020).

I also use as a reference the concept of 'action research' created by psychologist Lewin (1890-1947). Burnes (2004) provides an in-depth analysis of the relationship between this concept and Lewin's work. Here, I focus on the concept of 'action research', in line with Lewin's 1946 paper. The context in which the concept of 'action research' emerges can be found in Lewin's work, where he describes the beginning of a new stage of development in social sciences as one of the by-products of World War II. He identifies three main tendencies that, having started before the war, gained new ground to quickly develop afterwards: 1) integrating social sciences, 2) moving from the description of social bodies to the dynamic problems of changing group life, and 3) developing new social research instruments and techniques. In general, this represents a change in attitude and, unlike the previous situation, there is a call for "a relatively widespread recognition of the necessity of developing better concepts and higher levels of theory" (Lewin 1946, 5). This was the context that allowed for the growth of Systems Theory.

In his 1946 paper, Lewin reveals that the concept of 'action research' is created as a response to progress made by minority groups that have been having difficulty finding ways to maintain it and use it as a counterpressure, strong enough to reverse a trend. 'Action research' is the concept that aims to respond to this challenge, facilitating intergroup relations and providing research that helps the practitioner: "research that produces nothing but books will not suffice" (Lewin 1946, 35).

Lewin argues that $(1946,42-43)$ a strategy needs to be put in place to implement 'action research'. In turn, to design a strategy, the dangers involved need to be taken into account, distinguishing between outside adversities and barriers to social science and the inner dangers of research procedures. The first refers to people who claim that we do not need any more social science to solve any problems. One can only attempt to answer this with better science. The second threat refers to "groups in power" (management, labour leaders, politicians, some branches of government, etc.). In Lewin's $(1946,43)$ own words: "Somehow or other they all seem to be possessed by the fear that they could not do what they want to do if they, and others, would really know [sic] the facts". To this he replies that it is necessary to identify fears that are legitimate, recognising the difference "between fact-finding and policy setting to carefully study the procedures by which fact-finding should be fed into the social machinery of legislation to produce a democratic effect" (ibid., 43). He identifies a third perceived threat held by practitioners that expresses the fear they have that researchers, in the end, will tell the community what to do and what not to do. The point Lewin makes is that the researcher's job is to provide information that provides the practitioner with better diagnosis and treatment options. But it is up to the practitioner to decide how or whether to use it - and it is important that the researcher is also aware of this (Lewin 1946, 44). Most immediately, what social scientists can do (apart from writing books) is find ways to empower minority groups elevating their sense of "group esteem and group loyalty" which are essential for all groups in society. 
In this paper, we find an outline that permits identification of the main concerns to bear in mind concerning ULL at any stage: design, implementation, management, outputs and outcome phases. When it comes to creating new tools that promote interaction between different actors and stakeholders, these will depend on imagination and available new technologies. However, the threats identified by Lewin remarkably remain the same to the present day. Can these be overcome more effectively using ULL methodology, which could be said to be an instrument situated beyond governance, but not coinciding with government either? As it is both an upper hierarchy institution above government in some respects and also a supporter of bottom-up initiatives in some others, can the European Union, as a supranational entity, be an adequate framework for facilitating ULL and leading us to sustainability?

As proposed by Frantzeskaki and van Steenbergen $(2018,242)$, ULL are an embedded methodology. This means that "a lab can be "dropped" in a certain place [...] but then the actual design practices and processes are context-dependent". ULL always imply to create mechanisms that generate a social dynamic that slowly stands on its own. This can be a lengthy process, but to conceive successful solutions that address future challenges, it is a necessary one.

\section{Conclusion}

Technological innovation is at the centre of urban development and smart cities. However, I claim that the biggest challenge is at governance level in the social realm. Smart Cities favour technology, translating innovation into knowledge and the number of patents registered. But how can social innovation be designed, managed and assessed? Are ULL an effective methodology?

I have demonstrated that ULL stem from Systems Theory. This is important to establish that to effectively promote sustainable cities, which can find a balance between the economic, ecological and social realm, not only is it necessary to go beyond technology, but also to go beyond governance. Mazzucato (2013) shows us that governments should not be expended and that they should actively assume a leadership role when it comes to innovation. I go back to the question that motivated Lewin $(1946,1947)$ to create 'action research': can ULL promote positive change that lasts? At the time, Lewin answered that social scientists can only contribute to formulating better diagnoses and treatments, informing practitioners. What happens next and how the information is used will be there for the taking.

Nowadays, we are one step further along and the gap between those who perform the diagnoses and treatments and those who design and implement public polices has shrunk. Therefore, any strategy concerning the realm of cities should strive for a balance between bottom-up initiatives and top-down policies in its conceptual approach and implementation plan. This encompasses identifying relevant stakeholders, acknowledging each stakeholder's interests and conceptual language and carefully designing communication strategies. A mechanism should be put in place to constantly adapt, before, during and after the project, in order to effectively manage emerging tensions and assure a long-lasting impact. As we have seen, the four main activities of Living Labs are: co-creation, exploration, experimentation and evaluation. However, these just focus on implementation as a process while dismissing established systems. ULL can only become a successful methodology if it can find a balance between "process and system", between experimentation and pre-existing systems. Otherwise, the somewhat ethereal, temporary nature of ULL, combined with its experimental nature, will fail to deliver when it comes to concrete outputs and long-term outcomes. Following its experimental phase, it should follow a strategy that incorporates part of its results into the system, contributing to the system's renewal and improvement. Only then will the process of ULL be concluded. Ideally, ULL should be constantly active, working closely in parallel with existing systems and using action research methodology able to accurately inform future public policies.

In this sense, I claim that the biggest challenge to the successful implementation of the SC concept is the design of innovative governance systems. This is what will allow us to have sustainable SC. ULL can be a relevant methodology that allows us to transition between an old governance paradigm (torn between government and governance) to a new governance paradigm.

So that ULL can be efficient and effective in leading us in this direction: 1) along with Ruhlandt (2018) and van Geenhuizen (2018), I call for comparative qualitative analysis to better assess the 
results of the implementation of Living Labs across all stages - there is a wide-ranging difference of perspectives when it comes to smart cities governance and studies are more focused on one city and qualitative in nature, and 2) the public sector and public administration need to be subjected to the Living Labs methodology (Gascó 2017) so it can implement new open social innovation strategies that lead the way for other actors and stakeholders.

As for the contribution of geography to this, it is very positive to see that research is beginning to emerge concerning this subject. I highlight two main directions that I think have high potential to be developed further: 1) the impact of the use of technology in urban environments (Macrorie et al. 2019), and 2) the contribution of geography to Future Studies to anticipate challenges and better prepare the future (Jones 2019).

\section{Notes}

${ }^{1}$ A mapping of the concept is provided by van der Have and Rubalcaba (2016): social innovation is grounded in four distinct intellectual communities arising through a somewhat organised diffusion process: 1) Community Psychology, 2) Creativity research, 3) Social and societal challenges, and 4) Local development.

\section{Acknowledgements}

I would like to thank the two anonymous reviewers and Dr. Kirsi Pauliina Kallio, the Editor-in-Chief of Fennia, for their valuable comments and suggestions. This research was supported by the H2020 European funding on the project "ROCK: Regeneration and Optimization of Cultural Heritage in Creative and Knowledge Cities", hosted by Instituto de Ciências Sociais, Universidade de Lisboa, under the Grant Agreement Number 730280.

\section{References}

Agazzi, E. (1978) Theory and the problem of reductionism. Erkenntnis (1975-) 12(3) 339-358. http://www.jstor.org/stable/20010611

Agazzi, E. (2014) Scientific Objectivity and Its Contexts. Springer, Cham. https://doi.org/10.1007/978-3-319-04660-0 Almeida, V. A., Doneda, D. \& Costa, E. M. (2018) Humane smart cities: the need for governance. IEEE Internet Computing 22 91-95. https://doi.org/10.1109/MIC.2018.022021671

von Bertalanffy, L. (1968) General System Theory: Foundations, Development, Applications. George Brazziler, New York.

Boons, F. \& McMeekin, A. (eds.) (2019) Handbook of Sustainable Innovation. Edward Elgar, Cheltenham and Northampton, MA. https://doi.org/10.4337/9781788112574

Brundtland Commission (1987) Our Common Future. Oxford University Press, Oxford.

Bulkeley, H., Marvin S., Palgan Y.V., McCormick, K., Breitfuss-Loidi, M., Mai, L., von Wirth, T. \& Frantzeskaki, N. (2019) Urban living laboratories: conducting the experimental city? European Urban and Regional Studies 26(4) 317-335. https://doi.org/10.1177/0969776418787222

Burnes, B. (2004) Kurt Lewin and complexity theories: back to the future? Journal of Change Management 4(4) 309-325. https://doi.org/10.1080/1469701042000303811

Caprotti, F. \& Cowley, R. (2017) Interrogating urban experiments. Urban Geography 38(9) 1441-1450. https://doi.org/10.1080/02723638.2016.1265870

Caragliu, A. \& Del Bo, C. F. (2018) Smart innovative cities: the impact of smart city policies on urban innovation. Technological Forecasting and Social Change 142 373-383. https://doi.org/10.1016/j.techfore.2018.07.022

Cardullo, P., Kitchin, R. \& Di Feliciantonio, C. (2018) Living labs and vacancy in the neoliberal city. Cities 73 44-50. https://doi.org/10.1016/j.cities.2017.10.008

Chronéer, D., Ståhlbröst, A. \& Habibipour, A. (2018) Towards a unified definition of Urban Living Labs. Presented at the ISPIM Innovation Conference - Innovation, The Name of The Game, Stockholm, Sweden on 17-20 June 2018, International Society for Professional Innovation Management (ISPIM). $<$ http://www. diva-portal.org/smash/record.jsf?pid=diva2\%3A1230360\&dswid=4491>. 17.6.2020.

EC (2016) The European Network of Living Labs (ENoLL) explained. European Commission. $<$ https:// ec.europa.eu/digital-single-market/en/news/european-network-living-labs-enoll-explained>. 17.6.2020.

ENoLL (2020) European Network of Living Labs (ENoLL) Official Website. <https://enoll.org/>. 17.6.2020. 
Europeana (2020) Introducing ENoLL, the European Network of Living Labs. Europeana. <https://pro. europeana.eu/post/introducing-enoll-the-european-network-of-living-labs>. 17.6.2020.

Frantzeskaki, N. \& van Steenbergen, F. (2018) The importance of place for urban transition experiments: understanding the embeddedness of urban living labs. In Marvin, S., Bulkeley, $\mathrm{H}_{\text {, }}$ Mai, L., McCormick, K. \& Palgan, Y. V. (eds.) Urban Living Labs: Experimenting with City Futures, 231-247. Routledge, London. https://doi.org/10.4324/9781315230641

Gaffney, C. \& Robertson, C. (2016) Smarter than smart: Rio de Janeiro's flawed emergence as a smart city. Journal of Urban Technology 25(3) 47-64. https://doi.org/10.1080/10630732.2015.1102423

Gascó, M. (2017) Living labs: implementing open innovation in the public sector. Government Information Quarterly 34(1) 90-98. https://doi.org/10.1016/j.giq.2016.09.003

van Geenhuizen, M. (2018) A framework for the evaluation of living labs as boundary spanners in innovation. Environment and Planning C: Politics and Space 36(7) 1280-1298. https://doi.org/10.1177/2399654417753623

Godin, B. (2015) Innovation Contested: The Idea of Innovation Over the Centuries. Routledge, London. https://doi.org/10.4324/9781315855608

Godin, B. \& Gaglio, G. (2019) How does innovation sustain ‘sustainable innovation'? In Boons, F. \& McMeekin, A. (eds.) Handbook of Sustainable Innovation, 27-37. Edward Elgar, Cheltenham, UK, and Northampton, MA. https://doi.org/10.4337/9781788112574.00007

Goodspeed, R. (2015) Smart cities: moving beyond urban cybernetics to tackle wicked problems. Cambridge Journal of Regions, Economy and Society 8(1) 79-92. https://doi.org/10.1093/cjres/rsu013

van der Have, R. P. \& Rubalcaba, L. (2016) Social innovation research: an emerging area of innovation studies? Research Policy 45(9) 1923-1935. https://doi.org/10.1016/j.respol.2016.06.010

Hobsbawm, E. J. (2012) Nations and Nationalism Since 1780. Cambridge University Press, Cambridge.

Hossain, M., Leminen, S. \& Westerlund, M. (2018) A systematic review of living lab literature. Journal of Cleaner Production [online Jan 9 2019]. https://doi.org/10.2139/ssrn.3307055

Jones, R. (2019) Governing the future and the search for spatial justice: Wales' Well-being of Future Generations Act. Fennia 197(1) 8-24. https://doi.org/10.11143/fennia.77781

Keith, M., O'Clery, N., Parnell, S. \& Revi, A. (2020) The future of the future city? The new urban sciences and a PEAK Urban interdisciplinary disposition. Cities 105102820. https://doi.org/10.1016/j.cities.2020.102820

Kronsell, A. \& Mukhtar-Landgren, D. (2018) Experimental governance: the role of municipalities in urban living labs. European Planning Studies 26(5) 988-1007. https://doi.org/10.1080/09654313.2018.1435631

Lara, A. P., Moreira Da Costa, E., Furlani, T. Z. \& Yigitcanlar, T. (2016) Smartness that matters: towards a comprehensive and human-centred characterisation of smart cities. Journal of Open Innovation: Technology, Market, and Complexity 2(8). https://doi.org/10.1186/s40852-016-0034-z

Lam, P. T. I. \& Ma, R. (2019) Potential pitfalls in the development of smart cities and mitigation measures: an exploratory study. Cities 91 146-156. https://doi.org/10.1016/j.cities.2018.11.014

Leminen, S. \& Westerlund, M. (2012) Towards innovation in Living Labs networks. International Journal of Product Development 17 (1-2). https://doi.org/10.1504/IJPD.2012.051161

Leminen, S., Westerlund, M. \& Nyström, A-G. (2013) On becoming creative consumers - user roles in living labs networks. International Journal of Technology Marketing 9(1). https://doi.org/10.1504/IJTMKT.2014.058082

Lewin, K. (1946) Action research and minority problems. Journal of Social Issues 2(4) 34-46. https://doi.org/10.1111/j.1540-4560.1946.tb02295.x

Lewin, K. (1947) Frontiers in group dynamics: concept, method and reality in social science; social equilibria and social change. Human Relations 1(1) 5-41. https://doi.org/10.1177/001872674700100103

Luhmann, N. (2013) Introduction to Systems Theory. Translated by Peter Gilgen. Polity Press, UK.

Lupova-Henry, E. \& Dotti, N. F. (2019) Governance of sustainable innovation: moving beyond the hierarchy-market-network trichotomy? A systematic literature review using the 'who-how-what' framework.Journal of Cleaner Production 210 738-748. https://doi.org/10.1016/j.jclepro.2018.11.068

Macrorie, R., Marvin, S. \& While, A. (2019) Robotics and automation in the city: a research agenda. Urban Geography [online Dec 31 2019] https://doi.org/10.1080/02723638.2019.1698868

Mazzucato, M. (2013) The Entrepreneurial State: Debunking Public vs. Private Sector Myths. Anthem Press, London.

Mazzucato, M. (2018) The Value of Everything: Making and Taking in the Global Economy. Public Affairs, New York.

McFarlane, C. \& Söderström, O. (2017) On alternative smart cities. City 21(3-4) 312-328. https://doi.org/10.1080/13604813.2017.1327166 
Mukhtar-Landgren, D., Kronsell, A., Palgan, Y. V. \& von Wirth, T. (2019) Municipalities as enablers in urban experimentation. Journal of Environmental Policy \& Planning 21(6) 718-733. https://doi.org/10.1080/1523908X.2019.1672525

Parsons, T. (1991) The Social System. Routledge, London.

Perng, S.-Y. \& Maalsen, S. (2019) Civic infrastructure and the appropriation of the corporate smart city. Annals of the American Association of Geographers 110(2) 507-515. https://doi.org/10.1080/24694452.2019.1674629

Pol, E. \& Ville, S. (2009) Social innovation: buzz word or enduring term? The Journal of Socio-Economic 38(6) 878-885. https://doi.org/10.1016/i.socec.2009.02.011

Porter, T., \& Córdoba, J. (2008) Three views of systems theories and their implications for sustainability education. Journal of Management Education 33(3) 323-347. https://doi.org/10.1177/1052562908323192

ROCK (2020) <https://rockproject.eu/>. 17.6.2020.

Roux, E. \& Marron, Q. (2016) Observing living labs to imagine tomorrow's metropolises. Open LivingLab Days 2016, European Network of Living Labs, Aug 2016, Montréal, Canada. <https://hal.archivesouvertes.fr/hal-01551405>. 17.6.2020.

Ruhlandt, R. W. S. (2018) The governance of smart cities: a systematic literature review. Cities 81 1-23. https://doi.org/10.1016/j.cities.2018.02.014

Sabatier, P. A. (1986) Top-down and bottom-up approaches to implementation research: a critical analysis and suggested synthesis. Journal of Public Policy 6(01) 21-48. https://doi.org/10.1017/s0143814x00003846

Schuurman, D., De Marez, L. \& Ballon, P. (2017) Living labs: a systematic literature review. University of Ghent. <https://biblio.ugent.be/publication/7026155/file/7026171>. 17.6.2020.

Soeiro, D. (2020a) Smart cities, well-being and good business: the 2030 Agenda and the role of knowledge in the era of Industry 4.0. In Matos, F., Vilarinhos, V., Salavisa, I., Edvinsson, L. \& Massaro, M. (eds.) Knowledge, People and Digital Transformation: Approaches for a Sustainable Future, 41-53. https://doi.org/10.1007/978-3-030-40390-4_5

Soeiro, D. (2020b) The concept of atmosphere: from Goethe to Bratton - how atmosphere is key to create smart cities. In Abusaada, H., Salama, A. M. \& Elshater, A. (eds.) Reconstructing Urban Ambiance in Smart Public Places, 23-40. https://doi.org/10.4018/978-1-7998-3856-2.ch002

Taylor, L. (2020) Exploitation as innovation: research ethics and the governance of experimentation in the urban living lab. Regional Studies [online] https://doi.org/10.1080/00343404.2020.1826421

Tomor, Z., Meijer, A., Michels, A. \& Geertman, S. (2019) Smart governance for sustainable cities: findings from a systematic literature review. Journal of Urban Technology 26(4) 3-27. https://doi.org/10.1080/10630732.2019.1651178

UN (2020a) United Nations Agenda 2030 Website. <https://sustainabledevelopment.un.org>. 17.6.2020.

UN (2020b) United Nations - Department of Economic and Social Affairs. Participation and accountability. <https://publicadministration.un.org/en/developmentmgt>. 17.6.2020.

Walker, D. M. (2012) Urban geography. In Stoltman, J. P. (ed.) 21 $1^{\text {st }}$ Century Geography: A Reference Handbook, 289-300. Sage, Los Angeles, CA.

Wiig, A. \& Wyly, E. (2016) Introduction: thinking through the politics of the smart city. Urban Geography 37 (4) 485-493. https://doi.org/10.1080/02723638.2016.1178479

von Wirth, T., Fuenfschilling, L., Frantzeskaki, N. \& Coenen, L. (2019) Impacts of urban living labs on sustainability transitions: mechanisms and strategies for systemic change through experimentation. European Planning Studies 27(2) 229-257. https://doi.org/10.1080/09654313.2018.1504895

Yigitcanlar, T. (2016) Technology and the City: Systems, Applications and Implications. Routledge, New York. https://doi.org/10.4324/9781315739090

Yigitcanlar, T., Kamruzzaman, M., Buys, L., Ioppolo, G., Sabatini-Marques, J., da Costa, E. M. \& Yun, J. J. (2018) Understanding "smart cities": intertwining development drivers with desired outcomes in a multidimensional framework. Cities 81 145-160. https://doi.org/10.1016/j.cities.2018.04.003

Yigitcanlar, T., Kamruzzaman, M., Foth, M., Sabatini, J., da Costa, E., \& loppolo, G. (2019) Can cities become smart without being sustainable? A systematic review of the literature. Sustainable Cities and Society 45 348-365. https://doi.org/10.1016/j.scs.2018.11.033 